ONDŘEJ PŘIBYL, Ph.D.

E-mail: pribylo@fd.cvut.cz

Department of Applied Mathematics

Czech Technical University in Prague,

Faculty of Transportation Sciences

Na Florenci 25, Praha 1, 11000, Czech Republic

MILAN KOUKOL, Ph.D.

E-mail: koukol@fd.cvut.cz

Department of Applied Informatics in Transportation

Czech Technical University in Prague,

Faculty of Transportation Sciences

Konviktská 20, Praha 1, 11000, Czech Republic

JANA KUKLOVÁ

E-mail: kuklojan@fd.cvut.cz

Czech Technical University in Prague,

Faculty of Transportation Sciences

Department of Applied Mathematics

Na Florenci 25, Praha 1, 11000, Czech Republic
Intelligent Transport Systems (ITS)

Review

Submitted: Oct. 30, 2014

Approved: Oct. 6, 2015

\title{
COMPUTATIONAL INTELLIGENCE IN HIGHWAY MANAGEMENT: A REVIEW
}

\begin{abstract}
Highway management systems are used to improve safety and driving comfort on highways by using control strategies and providing information and warnings to drivers. They use several strategies starting from speed and lane management, through incident detection and warning systems, ramp metering, weather information up to, for example, informing drivers about alternative roads. This paper provides a review of the existing approaches to highway management systems, particularly speed harmonization and ramp metering. It is focused only on modern and advanced approaches, such as soft computing, multi-agent methods and their interconnection. Its objective is to provide guidance in the wide field of highway management and to point out the most relevant recent activities which demonstrate that development in the field of highway management is still important and that the existing research exhibits potential for further enhancement.
\end{abstract}

\section{KEY WORDS}

traffic management; traffic control systems; congestion; soft computing; multi-agent systems;

\section{INTRODUCTION}

With the increasing travel demand the highway network is often insufficient nowadays. One of the possible approaches is in building new roads; certainly not economically and often not even a technically available option. For this reason, the use of intelligent transport systems (ITS) is an available and necessary tool. On highways, the ITS components are combined together with other management strategies into socalled highway management systems (HMS).

HMS are typically addressing one or more of the following objectives:

1) Decrease of the number and impact of regular congestions;

2) Decrease of the number and impact of irregular congestions;

3) Increase of traffic safety.

There are many different control strategies that can be used to address the aforementioned objectives. The reference [1] provides an overview of particular strategies (see Figure 1). Furthermore, it describes the strategies in more detail and illustrates them with examples.

This paper is focused mainly on speed harmonization and ramp metering, and the authors examine the usage of soft computing approaches to these strategies. The focus is set on these two strategies mainly for their nature (both belong to the field of traffic control) and since they have not been sufficiently addressed by any existing review.

Other strategies presented in Figure 1, such as automated incident detection (AID), are not further discussed in this paper, since they have been thoroughly examined by other researchers and the soft computing methods have been widely used $[2,3]$. Other topics, such as traffic enforcement, are typically subject to 


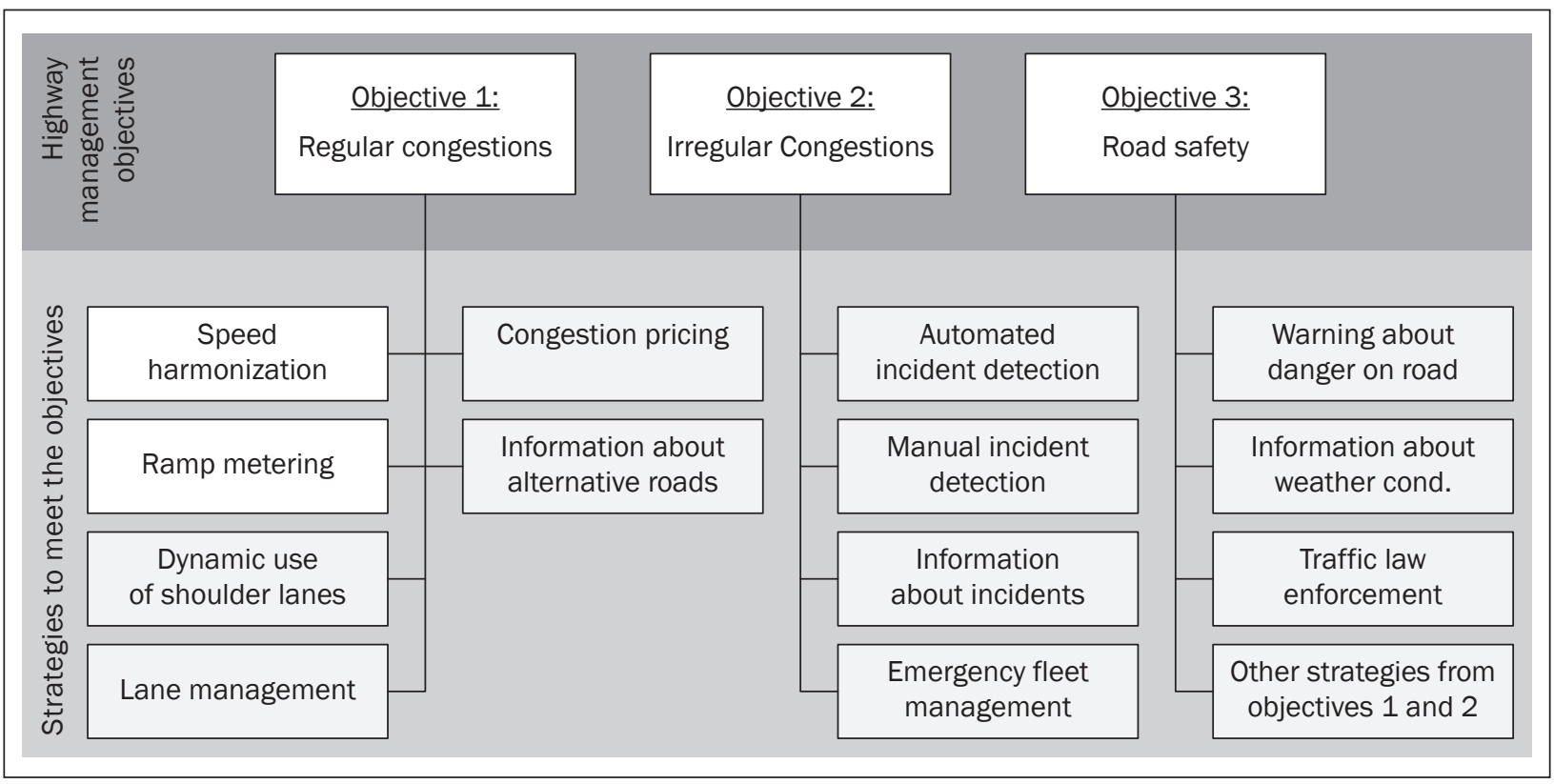

Figure 1 - Major highway management strategies and definition of the scope of this paper

certification by authorities and do not use soft computing methods at all. For this reason, the authors decided to focus only on the abovementioned topics. The remaining strategies (such as warning about danger on roads) are discussed only when they are treated jointly with speed harmonization and/or ramp metering.

The major objective of this paper arose during author's own research work on highway management. There has been no survey of the existing approaches to highway management with respect to modern approaches such as soft computing or distributed architecture. At the same time, their usage for the given field is rather intuitive. This is certainly a complication when starting a new research. For this reason, this paper aims at providing an overview of the existing methods and their achievements, showing the recent trends, and at the same time summarizing the identified limits of particular approaches. The paper, however, does not provide any own evaluation of the presented methods, nor does it describe the particular management strategies or particular control methods in more details.

\section{APPROACHES TO HIGHWAY MANAGEMENT}

Many different approaches to highway management can be encountered nowadays, e.g. model predictive control [4], support vector machines [5], chaos theory [6], etc. Since it is not possible to cover all of them within this paper, the focus here is only on the important and modern approaches: soft computing and multi-agent systems.

Soft computing is originally a branch of artificial intelligence; however, it has developed to follow its own path. Soft computing differs from conventional computing in that it is tolerant of imprecision, uncertainty, partial truth, and approximation [7]. The methods belonging to this field are motivated by human mind and human reasoning. Because soft computing does not focus on symbolic manipulation in the way artificial intelligence does, but rather uses extensive numerical computation, it is also known as computational intelligence.

Soft computing consists of the following major areas:

- Fuzzy systems (FS);

- Artificial neural networks (ANN);

- Evolutionary or genetic algorithms (GA); or

- Probabilistic reasoning (PR).

The following features characterize soft computing (adopted from [8]):

- It is meant to describe and understand human expertise;

- It consists of biologically inspired computing models and new optimization techniques;

- It uses strong numerical computation and so called model-free learning;

- It is meant to be used in new application domains from real- world;

- The methods aim to be robust and fault tolerant and are meant to be used for solving non-linear tasks.

It is obvious that the problems in the field of highway management are very good candidates for soft computing since they are usually strongly non-linear, often described in linguistic terms, and the output should be understood by humans. Since they have also a highly distributed structure and are comprised of several strategies which, however, seek a joint ob- 
jective function, considering the so-called multi-agent systems (MAS) within this review is rather natural. Loia [9] introduces the concept and advantages of combining MAS and soft computing methods:

"Agents or Multi-Agent Systems sketch intelligent behaviours by describing and managing computational activities shared over communities of large-grain entities. [...]

Soft Computing, and in particular Fuzzy Technology, may play an important role in the design of smart agents. Promising benefits derive from well-founded soft computing -oriented approaches in order to better manage the behavioural models of the agents, especially when the interactions occur in an environment characterized by imprecision, uncertainty, and partial truth."

\section{APPLICATION OF SOFT-COMPUTING METHODS}

\subsection{Speed harmonization}

Speed harmonization is typically applied in case of big traffic volume and large speed deviation. The interactions between slow-moving and fast-moving vehicles increase the probability and the severity of traffic accidents, decrease road capacity and increase travel time.

Speed harmonization is achieved by means of decreasing the speed limit on a given highway segment. Based on measurement of the actual traffic flow characteristics and its predictions, the system proposes the most suitable speed limit, which is displayed on a gantry above the given lane. Typically, data not only from the given road segments, but also from adjacent segments are used. In the next steps, the algorithms have to harmonize the speed limit between particular lanes and between particular road segments, so that only consistent and stable speed limits are presented. The new speed limit is presented to drivers by means of variable message signs. This highway management strategy is also called "variable speed limit control" (VSLC).

Implying the speed limits does not only influence the average speed, but also the speed deviation. This leads not only to significant safety improvements, but also to the decrease of the distance between vehicles and, thus, to the increase of road capacity.

The most common approaches to speed harmonization use relatively simple decision trees, which, based on increase of certain traffic variables, impose a new speed limit. A concise approach using decision trees is provided for example in German standards [9]. This can be recommended as a major overview and reference to speed harmonization. The authors provide an overview of the overall structure of highway management system, references on the data pre-processing, and recommend an appropriate harmoniza- tion algorithm. This algorithm uses three variables to manage speed: intensity (veh/time), speed $(\mathrm{km} / \mathrm{h})$, and local traffic density (veh/km), which is computed from intensity and speed. In order to avoid quick changes of speed limits (oscillation), a hysteresis is introduced through usage of different decision trees for turning on and turning off the speed limits.

Several other authors use decision tree approach as well. They usually aim to improve the control algorithm using different conditions and/or variables for VSLC. For example Kühne and Langbein [11] use standard deviation of speed distribution besides intensity (veh/time), speed (km/h) and traffic density (veh/km). They start to decrease the speed limit already in case of relatively low intensity (approximately 60 - 80\% of road capacity), but higher standard deviation of speeds. The parameter of standard deviation of speed is also used by Gu et al. [12]. The authors studied the relations between speed deviation and other traffic parameters on the basis of data from highway G6 in Beijing (China). The resulting algorithm does not present any significant improvement to other algorithms discussed within this review. Allaby et al. [13] use intensity (veh/time), occupancy (\%) and average speed $(\mathrm{km} / \mathrm{h})$. However, they use their algorithm mainly to evaluate its effect on traffic conditions.

On the other side, Jo and Kim [14] focus on safety aspects. For this reason, next to using speed $(\mathrm{km} / \mathrm{h})$ as usual in other algorithms, they use speed difference between a particular station (gantry) and a station located upstream. Additionally, they use a variable called shock wave, which is computed based on intensity (veh/time) and density (veh/km). The last variable aims at detecting traffic congestion. The authors claim that the novelty of this algorithm consists in taking into consideration multiple stations, but according to the literature review, similar approaches are to be found even in the MARZ [9].

An interesting improvement of VSLC algorithms is called INCA [15]. Here the authors aim to improve the MARZ algorithm by introducing an objective function. The objective function used within [15] takes into consideration the value of lost time, cost of an accident, probability of an accident and the average speed. The original MARZ algorithm was optimized with the usage of existing data and the proposed objective function. This approach enables setting the decision criteria in an automated way, without the need of engineering knowledge for the optimization, as most of other algorithms do. It is an example of a data driven approach.

The next large group of algorithms presented by the researchers belongs to the field of fuzzy logic. Fuzzy control algorithms represent the first natural enhancement of the common control algorithms mentioned above. So far, we have dealt only with those algorithms where a slight change of measured parameters, caused by even one vehicle, can significantly change 
the control strategy (i.e. turning on different speed limit). This is certainly not an expected behaviour of a control algorithm, and fuzzy control systems are able to face this problem. They also allow the usage of linguistic variables and the usage of expert knowledge during the model induction phase.

The application of fuzzy logic in the control systems for traffic management has a long history. The first approaches were presented by Japanese authors Sasaki and Akiyma in the late 1980s [16, 17]. They adopted a control system for an on-ramp at urban expressway. At that time the traffic management was in hands of skilled traffic operators. The authors successfully demonstrated that this complex operator's judgment process can be replaced by a fuzzy control system.

From the long list of the early fuzzy control systems adapted to highway management, we would like to point out several papers. Wang et al. [18] provide an interesting approach by introducing a multi-level fuzzy control algorithm. The paper introduces high modularity and avoids the problem known as the "curse of dimensionality" [19]. When dealing with speed harmonization, they propose a three-level fuzzy model. Pavement condition and weather condition are concerned in the first level sub-model. The second level sub-model combines the outputs from the first level and provides information on driving conditions. The third level sub-model uses traffic density and driving conditions (output from the second level) as inputs and provides the final recommendations corresponding to the speed limit displayed on the variable message signs (VMS).

The issue of fuzzy logic for speed harmonization was strongly propagated, for example, by Federal Highway Administration in the USA. The results of the research project Fuzzy Variable Speed Limit Project [20, 21] strongly recommend the usage of fuzzy logic for speed harmonization.

Roshandeh et al. [22] suggest a rather simple algorithm for speed harmonization. The authors use only two input variables: speed (veh/ km) and intensity (veh/time). Such an approach represents a straightforward extension of the rule-based algorithms, but it lacks any further comparison to other methods.

Most of other fuzzy controllers were used in combination with ramp metering. Thus, their overview is provided in the following section which is dedicated to ramp metering.

Genetic algorithms have been used in the field of highway management mainly in combination with fuzzy logic. The reason is obvious. The major problem with fuzzy systems is identification of their parameters. Often only expert knowledge or even expert judgment is used to set their parameters and such systems cannot be easily reused for other locations. Genetic algorithms generally allow adopting of the parameters of fuzzy systems based on existing data and defined objective function.
Chiou and Lan [23] provide a novel bi-level iterative algorithm, which uses genetic algorithms to compose the logical rules of a fuzzy control system in the first stage, and then determines their shape on the second stage. They also present a new way to encode the chromosomes to overcome a problem of many constraints in applying particular genetic operators. The authors validate this algorithm by the application to car-following model. They also compare it to different algorithms, such as simple fuzzy controller or a model using artificial neural networks. Their results are truly encouraging.

Chiou et al. [24] then apply the control algorithm presented above to the speed harmonization problem. Unlike most other authors, they use a cell transition model (mesoscopic models) to evaluate the performance of the control algorithm. The objective function used for calibrating the control system combines crash likelihood and throughput in order to take into consideration safety as well as driving comfort. The scenario with speed harmonization was compared to the situation without control. The results show that it is possible to decrease the crash likelihood without depriving of driving comfort.

\subsection{Ramp metering}

Ramp meters are special traffic signals at the end of a freeway on-ramp that regulate the flow of traffic onto the mainline. This is done based on information from sensors located on the ramp as well as on the highway. The main purpose of ramp meters is to keep the mainline of the freeway from becoming overly congested, and to maximize the efficient use of freeway capacity. This is achieved not only through limiting the number of incoming vehicles, but also through improved merging behaviour of the incoming vehicles, which has been proven by several field studies.

In general ramp metering aims at achieving the overall system optimum in the network through improving the performance of high-volume highway. It can, however, lead to building of on-ramp queues due to the introduced traffic signal.

Probably the most widely accepted ramp metering algorithm is ALINEA - a local feedback control algorithm [25, 26]. ALINEA is a feedback ramp metering policy, which attempts to maximize the mainline throughput by maintaining a desired occupancy on the downstream mainline freeway (for this reason local algorithm). This algorithm is often used as a reference model for comparison of different control systems or as a basis for further enhancement.

One of the improvements presented by the authors of the original ALINEA is provided in [27]. The system called HERO coordinates the local ramp metering actions on a highway with several on-ramps. They aim at improvement with respect to the two most common 
drawbacks of other methods: feed-forward (rather than feedback) nature of the control approach and the need for a predefined target flow capacity value.

An interesting overview of ramp metering algorithms is provided in [28] and [29]. Even though there are many different control algorithms, we will focus on those using soft computing methods only. An overview of approaches using fuzzy systems, neural networks and agent-technologies for ramp metering is provided in [30].

More recently, Murat et al. [31] described a fuzzy logic based approach to dual lane ramp metering (FuLCRMe). The paper is unique in the focus on two lanes approaching a freeway and in the usage of SIDRA [32], i.e. mesoscopic simulation for intersection control implemented in MS Excel for model evaluation. The authors claim that their model gives better results compared to "conventional model". Unfortunately, this conventional model is not described in more details and is probably the one implemented in SIDRA by default. Certainly, more evaluation is needed in this case.

Hsu and Hsieh [33] developed a coordinated fuzzy logic based control system, which should be implemented instead of the common local traffic responsive control algorithm used widely in Taiwan nowadays. The improvements consist in the increased robustness and decreased sensitivity to imprecise information of fuzzy control systems and the usage of additional inputs describing the traffic flow on the main freeway and thus coordinating four different ramp metering systems. The authors describe the proposed algorithm in more detail and provide the results of simulation in VISSIM, which suggests promising results for the selected case study.

Jiang and Liang [34] proposed an adaptive fuzzy system, which is used to tune parameters of the traditional PID (proportional-integral-derivative) controller. However, the evaluation within this paper is rather simplistic and further research should be conducted.

In general, the usage of neural networks directly for traffic control is not very common. There are several reasons why it is not recommended. Neural networks do not enable us to see and directly interpret the reasoning mechanisms due to its black box characteristics. Nevertheless, some interesting approaches have been adopted, e.g. [35], with respect to ramp metering. Here, the neural network is used to adopt parameters of the traditional I and PI controllers. In this way, the mentioned drawback of neural networks is eliminated and, on the other hand, its adaptive abilities are used.

Feng et al. [36] used adaptive fuzzy-neuro system to tune the parameters of the fuzzy control system. This paper, however, lacks any further evaluation of results and comparison to other methods.

The reasons for using the genetic algorithm to enhance the performance of fuzzy systems have been mentioned above. Several publications addressed this topic to ramp metering combined with speed harmonization, e.g. Ghods et al. [37, 38]. Here, the total time spent by all vehicles in the network is used as objective function. The authors, however, do not provide sufficient details on the particular genetic operators. The authors focus on the description of the METANET model [39] and its extension, which is used for evaluation of the algorithm. The results are compared to the ALINEA controller based on several scenarios. These scenarios cover no-control, ALINEA controller, fuzzy-genetic ramp metering only and fuzzy-genetic ramp metering with speed limits. The empirical results of the fuzzy-genetic ramp metering were very close to the original ALINEA controller; however, its performance was more suitable for praxis due to limited oscillations. Superior performance was achieved when ramp metering was enhanced with the speed limits on the main stream. This supports the expectations, that a joint objective function should be addressed by several highway management strategies.

Yu et al. [40] used the genetic algorithm to improve the performance of the fuzzy logic control (FLC) system. The main goal of the genetic algorithm is the tuning of the parameterized membership function of each fuzzy input. The authors compared the performances of the genetic fuzzy logic control (GFLC) ramp metering to FLC ramp metering by calculating the percentage change of TTT (Total Travel Time). Both ramp metering algorithms (FLC, GFLC) were implemented and evaluated in the stochastic microscopic traffic simulator - Aimsun. The genetic fuzzy ramp metering showed more improvement on TTT than fuzzy logic control when traffic demands exceed road capacity.

Zhang et al. [58] proposed a novel approach, based on hierarchical fuzzy rule base systems (HFRBS) and genetic algorithms, to develop traffic congestion prediction systems from a high number of input variables where HFRBS is optimized by genetic algorithms.

In the recent approaches, ramp metering is mainly not considered as an independent strategy, but rather used in connection with speed harmonization on the main freeway flow. This is a logical attitude, since we typically aim at optimization of the overall throughput and not only throughput of the incoming vehicles. The goal of ramp metering is to prevent vehicles from entering bottlenecks. For this reason, a larger set of publications addresses both of these topics simultaneously [41].

\subsection{General highway management using agents}

The trend of aiming the target jointly by several control strategies (from Figure 1) is confirmed also by the application of distributed intelligent systems. This is supported by the fact that heterogeneous agents (which can cover different strategies) cooperatively 
optimize a single common objective function, e.g. maximize road capacity and/or minimize crash probability (safety improvements). For this reason, the multi-agent systems usually focus on a combination of strategies, or on supporting decision-making of highway operators. An overview of interesting papers follows.

Roseman [42] proposes the concept of a multiagent "Incident Manager" control architecture for The Santa Monica Freeway Smart Corridor. The main part of the traffic management in the Smart Corridor is a knowledge-based expert system based on dynamic incident detection, analysis, and response. The expert system software is used to assign incident management responsibilities to agency operators on the action, or implementation level. The main tasks of "Incident Manager" are: monitoring traffic conditions, performing incident detection, and assigning probable location of each identified potential incident. If "Incident Manager" confirms an incident, the expert system develops a response plan. The response plan contains two types of elements: goals and actions. The goals of the response plan are "general management strategies" and the actions are "goal-supporting implementation commands" (a specific text message on a variable message sign).

Logi and Ritchie [43] describe an innovative multiagent architecture CARTESIUS (Coordinated Adaptive Real-Time Expert System for Incident management in Urban Systems) for the provision of real-time decision support to Traffic Operations Centre personnel for coordinated inter jurisdictional traffic congestion management on freeway and arterial networks. This work is an extension of the Logi's dissertation thesis [44]. They proposed a two-agent-based support for incident management operations on a freeway and an adjacent arterial sub network, and interact with human operators, determining control recommendations in response to the occurrence of incidents. The incident management is used for the analysis of congestion and generation of suitable network-wide, integrated responses on the freeways and arterials. Each agent collects real-time data from the traffic detectors and the data representing current status of the control devices (signals ramp meters and VMS). The authors make a simulation of 18 different incident scenarios and obtain a result that the traffic conditions were improved, with an average travel time per-vehicle reduction of $7.4 \%$.

Katwijk and Koningsbruggen [45] confirm the above mentioned findings through two simple examples. The first one, in which consecutive ramp metering installations coordinate their actions to promote the flow at a downstream bottleneck and, the second one, in which traffic management instruments coordinate their actions to attain a common goal on the network level. The second example is a coordination of the network with VMS used for route guidance. The authors tried to prove the possibility of cooperation be- tween the dynamic traffic management instruments. Concepts from the domain of agent and multi-agent systems were used for description of the traffic management instruments which were employed in the examples. In the next phase of the project, the authors wanted to validate their ideas in a laboratory environment [46].

Hernández et al. [47] share their experience with agent-based architectures for intelligent traffic management systems (ITMS). They also describe and compare integrated TRYS [48, 49] (i.e. an agent-based environment for building ITMS applications for motorway networks) and TRYS with autonomous agents [50, 51]. Two multi-agent systems that provide support to the decision makers in real-time traffic management in the urban motorway network around Barcelona. The traffic management agent, as described by the authors, firstly diagnoses the traffic problems present in a local area together with an explanation justifying such a diagnosis, and secondly proposes control actions for the available signal devices to improve traffic conditions using the diagnosis information. Thus, a traffic management agent has to provide two types of information: diagnosis of the traffic problems present in a local area (incident congestion or overflowing congestion) and propose control actions for the available signal devices (VMS panel displays, signals ramp meters). Authors performed on-line and laboratory tests with very positive results.

The work of Tomás and Garcia [52] explains the main features of the abovementioned MAS - its ontology, agents, interaction protocols as well as its behaviour when an incident is detected (vehicle accidents, meteorological problems, road civil works, public events, etc.) by a traffic administration in a real traffic scenario at the A3 Spanish freeway. Authors use “Traffic Management Plans" procedures (TMPs) which define how to manage the detected traffic incidents. The proposed TMPs can use two types of dynamic measures: The first one serves for calculation of alternative itineraries and to transfer information to drivers via dynamic signal, the second one provides information to a driver via a variable signal. The MAS prototype contains several kinds of agents: Meteo agents, manager agent, XML plan agent, web agent, DF agent and Interface agent. The proposed system has been implemented using the JADE platform and application of MAS together with the TMPs to improve a traffic conditions.

Katwijk et al. [46] present a test-bed for multi-agent control systems in road traffic management. The testbed aids in-depth research in this field. It is demonstrated by means of two example scenarios they have implemented:

1) Coordination of traffic management instruments on a freeway corridor.

The authors developed a multi-agent system 
which is capable of communicating about the required amount of metering. Proposed communication between the ramp metering installations improves awareness of future congestion. The reaction time in the detection of queue is shorter. The result is a 5 percent improvement in freeway travel time.

2) Coordination of traffic management instruments in a network.

The authors developed a multi-agent system which is capable of coordinating the actions of the ramp-metering installation and the VMS.

The main contribution of [46] to the research in the field of road traffic management is the development of a software environment for rapid development of multi-agent control systems.

Katwijk et al. [53] lay out the benefits of multi-agent coordination and propose a procedure through which such coordination among traffic control instruments can be achieved. In this procedure, each of the agents works fully autonomously and works towards its own local performance maximization (in this case: minimizing travel time or maximizing capacity of a network). The authors chose an approach in which each infrastructure element in the network is represented by an agent. The agents are represented as a link, variable message sign, ramp metering installation, and traffic lights. Each agent is responsible for the performance of the link or node in the network it represents. The agents provide the controllers with the information needed for the link's performance maximization. This information is different for each type of controller (variable message sign, ramp-metering installation and traffic lights).

A new expert system is introduced in article [54]. The system supports traffic management when weather adversities occur and affect traffic in road network. The system uses multi-agent technology to work with the specific characteristics of traffic domain and it can work in two modes:

1) Coordination between the agents - all the agents work together in large networks;

2) When local communication problems arise, small groups of agents can work together to inform road users about traffic problems.

The traffic management system is composed of the following elements: meteorological station, variable message sign (VMS), data collection station and remote station. The drivers are informed by VMS or RDS-TMC (Radio Data System-Traffic Message Chanel) about incidents on the road. The authors used JADE platform for the implementation of the system and Drools was used for the implementation of the expert system.

Almejalli et al. [55] propose an intelligent decision support system based on multi-agent approach. In this system architecture, the whole traffic network is divided into sub-networks. There is a dedicated evaluation agent in each sub-network. Each agent contains three traffic subsystems: monitoring, ITC-DSS (Intelligent Traffic Control-Decision Support System), and devices control. The monitoring subsystem is used to determine the current traffic state, ITC-DSS assists an operator in prediction of the local performance and the last subsystem is used for monitoring and controlling available traffic devices. The agents work together with other (affected) agents through the so-called coordinator (a high level agent) and thus the agents are able to find an optimal global traffic action using intelligent traffic control. The system is able to calculate "the control action fitness" and "control action global performance". Local performance predicted by ITC-DSS is determined by three parameters: total time spent, total distance travelled, and total queue length. The Variable Direction Indication is used to direct traffic. The performance of this multi-agent-based decision support system was tested in a case study of a part of the traffic network in the Riyadh city of Saudi Arabia.

Vilenica et al. [56] suggest that such kinds of problems can be modelled using agent-oriented models and techniques. They demonstrate how to use a generic Multi-Agent-System architecture that supports both modelling and simulating of such an application. It shows the way of using such architecture for application, analysis and comparison of different traffic management strategies, inspired by different sources like network management, feedback control, or nature inspired coordination algorithms.

Tomás et al. [57] present another test-bed based on multi-agent concept. This test-bed is able to test several traffic information strategies in case of the incidents on the road network (weather problems, accidents, etc.). The users are then informed via VMS and RDS-TMC. It contains a knowledge model implemented by a set of basic agents. These agents can be easily configured and extended to aid in-depth research in this field. The test includes agents to control variable message signal, weather stations, data collection stations, etc. The test-bed interface is based on Google maps. It provides a realistic environment that facilitates implementation of the tested strategies to the real world situations. The test-bed is based on a three-layer architecture: the first layer is the real world (the road network), the second layer represents this real world modelled by ontologies, and the third layer is composed of a set of basic software agents to provide the test-bed functionality. The results of testing the study cases in the proposed test-bed are very positive. The authors inform that the test-bed enables creation of a complete real road network and uses the proposed architecture. 


\section{OVERVIEW OF CONTROL STRATEGIES}

The major objective of this paper was to map the complex environment of highway management and its many different control strategies, with respect to the modern approaches such as soft-computing and multiagent systems. Focusing on highway management is still very topical. For example, in the Czech Republic, after the first implementation on the Prague city ring in

Table 1 - A summary of the methods
2010, next generations of highway management strategies are under development. Based on the literature review presented here, the future implementation of advanced control approaches will be considered as enhancement of the currently implemented approach.

Table 1 provides an overview of the methods and basic overview of their conclusions. This is certainly a simplification, but it attempts to summarize the findings of this paper in a graphical form.

\begin{tabular}{|c|c|c|c|}
\hline Research group & Application domain & Tool & Key Features \\
\hline Vukanovic et al. [15] & $\begin{array}{l}\text { Highway } \\
\text { management }\end{array}$ & $\begin{array}{l}\text { Speed } \\
\text { harmonization }\end{array}$ & Improvement of the MARZ [10] algorithm \\
\hline $\begin{array}{l}\text { Sasaki, Akiyma } \\
\text { [16], [17] }\end{array}$ & $\begin{array}{l}\text { Highway } \\
\text { management }\end{array}$ & $\begin{array}{l}\text { Fuzzy control } \\
\text { algorithm }\end{array}$ & A control system for an on-ramp at urban expressway \\
\hline Wang et al. [18] & $\begin{array}{l}\text { Highway } \\
\text { management }\end{array}$ & $\begin{array}{l}\text { A multi-level fuzzy } \\
\text { control algorithm }\end{array}$ & $\begin{array}{l}\text { A three-level fuzzy model for speed harmonization; } \\
\text { only a proposal. }\end{array}$ \\
\hline Roshandeh et al. [22] & $\begin{array}{l}\text { Highway } \\
\text { management }\end{array}$ & $\begin{array}{l}\text { Fuzzy control } \\
\text { algorithm }\end{array}$ & $\begin{array}{l}\text { Two input variables used: speed }(\mathrm{veh} / \mathrm{km}) \\
\text { and intensity (veh/time); the system was modeled } \\
\text { in MATLAB }\end{array}$ \\
\hline $\begin{array}{l}\text { Papageorgiou, } \\
\text { Hadj-Salem, } \\
\text { Blosseville [25], [26] }\end{array}$ & Ramp metering & & A local feedback control algorithm (ALINEA) \\
\hline $\begin{array}{l}\text { Papamichail, } \\
\text { Papageorgiou [27] }\end{array}$ & Ramp metering & & $\begin{array}{l}\text { Improvement of the ALINEA [25], [26]; twenty } \\
\text { scenarios in freeway traffic-flow simulator METANET }\end{array}$ \\
\hline Murat et al. [31] & Ramp metering & $\begin{array}{l}\text { Fuzzy Logic Traffic } \\
\text { Signal Control }\end{array}$ & $\begin{array}{l}\text { A fuzzy logic based approach to dual lane ramp } \\
\text { metering (FuLCRMe); fifteen scenarios; simulation } \\
\text { study tests the FuLCRMe model performance } \\
\text { by Microsoft Excel }\end{array}$ \\
\hline Hsu and Hsieh [33] & Ramp metering & $\begin{array}{l}\text { Fuzzy Logic Control } \\
\text { Algorithm }\end{array}$ & A coordinated fuzzy logic based control system \\
\hline Jiang and Liang [34] & Ramp metering: & $\begin{array}{l}\text { Fuzzy Self-Adaptive } \\
\text { PID Controller }\end{array}$ & $\begin{array}{l}\text { An adaptive fuzzy system, used to tune parameters } \\
\text { of a traditional PID; simulated in MATLAB }\end{array}$ \\
\hline $\begin{array}{l}\text { Zhang and Ritchie } \\
\text { [35] }\end{array}$ & Ramp metering & $\begin{array}{l}\text { Using artificial } \\
\text { neural networks }\end{array}$ & $\begin{array}{l}\text { The neural network is used to adopt parameters } \\
\text { of the traditional I and PI controllers }\end{array}$ \\
\hline Feng et al. [36] & Ramp metering & $\begin{array}{l}\text { Fuzzy Neural } \\
\text { Network Control } \\
\text { Method }\end{array}$ & $\begin{array}{l}\text { An adaptive neuro-fuzzy system to tune } \\
\text { the parameters of the fuzzy control system; draft only }\end{array}$ \\
\hline Ghods et al. [37], [38] & $\begin{array}{l}\text { Ramp metering, } \\
\text { speed } \\
\text { harmonization }\end{array}$ & $\begin{array}{l}\text { A Genetic-Fuzzy } \\
\text { approach }\end{array}$ & $\begin{array}{l}\text { Using genetic algorithm to enhance performance } \\
\text { of fuzzy systems; description of a benchmark network } \\
\text { and simulation results of different scenarios }\end{array}$ \\
\hline Yu et al. [40] & Ramp metering & $\begin{array}{l}\text { A Genetic-Fuzzy } \\
\text { approach }\end{array}$ & $\begin{array}{l}\text { Using genetic algorithm to improve the performance } \\
\text { of the fuzzy logic control system; control system was } \\
\text { simulated in Aimsun }\end{array}$ \\
\hline Roseman [42] & $\begin{array}{l}\text { The concept of } \\
\text { the multi-agent } \\
\text { "Incident Manager" }\end{array}$ & & $\begin{array}{l}\text { The expert system software is used to assign incident } \\
\text { management responsibilities to agency operators } \\
\text { on the action or implementation level; draft only }\end{array}$ \\
\hline
\end{tabular}


Table 1 (continued) - A summary of the methods

\begin{tabular}{|c|c|c|c|}
\hline Research group & Application domain & Tool & Key Features \\
\hline $\begin{array}{l}\text { Logi and Ritchie } \\
\text { [43] }\end{array}$ & $\begin{array}{l}\text { Coordinated Adaptive } \\
\text { Real-Time Expert } \\
\text { System for Incident } \\
\text { management } \\
\text { in Urban Systems }\end{array}$ & & $\begin{array}{l}\text { An innovative multi-agent architecture for the provision of real-time } \\
\text { decision support to Traffic Operations Centre personnel for coordi- } \\
\text { nated inter jurisdictional traffic congestion management on free- } \\
\text { way and arterial networks; simulated a set of } 18 \text { incident scenari- } \\
\text { os with varying characteristics under different demand patterns }\end{array}$ \\
\hline $\begin{array}{l}\text { Katwijk and } \\
\text { Koningsbruggen } \\
{[45]}\end{array}$ & Traffic management & $\begin{array}{l}\text { An agent } \\
\text { technology }\end{array}$ & $\begin{array}{l}\text { The authors tried to prove the possibility of cooperation between } \\
\text { the dynamic traffic management instruments }\end{array}$ \\
\hline $\begin{array}{l}\text { Katwijk et al. } \\
{[46]}\end{array}$ & Traffic management & $\begin{array}{l}\text { An agent } \\
\text { technology }\end{array}$ & $\begin{array}{l}\text { A test-bed for multi-agent control systems in road traffic manage- } \\
\text { ment; the control system was simulated in Paramics (two scenarios) }\end{array}$ \\
\hline $\begin{array}{l}\text { Hernández et al. } \\
{[47]}\end{array}$ & Traffic management & $\begin{array}{l}\text { An agent } \\
\text { technology }\end{array}$ & $\begin{array}{l}\text { Two multi-agent systems that provide support to the decision } \\
\text { makers in real-time traffic management in the urban motorway } \\
\text { network around Barcelona }\end{array}$ \\
\hline $\begin{array}{l}\text { Tomás and } \\
\text { Garcia [52] }\end{array}$ & Traffic management & $\begin{array}{l}\text { An agent } \\
\text { technology }\end{array}$ & $\begin{array}{l}\text { "Traffic Management Plans" procedures define management of } \\
\text { detected traffic incidents; implemented using the JADE platform }\end{array}$ \\
\hline $\begin{array}{l}\text { Katwijk et al. } \\
{[53]}\end{array}$ & Traffic management & $\begin{array}{l}\text { An agent } \\
\text { technology }\end{array}$ & $\begin{array}{l}\text { The authors chose an approach in which each infrastructure } \\
\text { element in the network is represented by an agent; concept only }\end{array}$ \\
\hline Martí et al. [54] & Traffic management & $\begin{array}{l}\text { An agent } \\
\text { technology }\end{array}$ & $\begin{array}{l}\text { The system supports traffic management when weather } \\
\text { adversities occur and affect the traffic in the road network; } \\
\text { the system has been implemented using JADE platform } \\
\text { and the inference engine for the expert system has been } \\
\text { implemented using Drools }\end{array}$ \\
\hline $\begin{array}{l}\text { Almejalli et al. } \\
\text { [55] }\end{array}$ & Traffic management & $\begin{array}{l}\text { An agent } \\
\text { technology }\end{array}$ & $\begin{array}{l}\text { An intelligent decision support system based on multi-agent } \\
\text { approach; a traffic case-study was created for a part of the traffic } \\
\text { network in the Riyadh city of Saudi Arabia }\end{array}$ \\
\hline $\begin{array}{l}\text { Vilenica et al. } \\
{[56]}\end{array}$ & Traffic management & $\begin{array}{l}\text { An agent } \\
\text { technology }\end{array}$ & $\begin{array}{l}\text { A generic Multi-Agent-System (MAS) architecture for traffic } \\
\text { management; simulation of two different scenarios }\end{array}$ \\
\hline Tomás et al. [57] & Traffic management & $\begin{array}{l}\text { An agent } \\
\text { technology }\end{array}$ & $\begin{array}{l}\text { A test-bed based on multi-agent concept for weather incidences } \\
\text { information; a real road network between Madrid and Valencia } \\
\text { was modelled }\end{array}$ \\
\hline
\end{tabular}

\section{CONCLUSION}

It can be concluded that most of the speed harmonization algorithms are based on the ideas covered by MARZ. This is a rather straightforward method, but it is based on the principles of modularity and practicability. Some of the fuzzy-based approaches are further improving the results, which are however mostly based on simulation. However, a fair comparison is rather difficult. It is clear from the provided literature as well as other publications that even though nobody questions the effect of speed harmonization on traffic flow parameters and safety, there is no accepted methodology for evaluation and clear numerical evaluation is difficult.

The ramp metering algorithms discussed in literature are rather advanced. Based on foundations of traffic flow theory and control engineering, researchers proposed and evaluated different settings, using local feedback control system or even data from adjacent freeway sections. There is clear focus on the fuzzy control approaches and their combination with other soft computing methods, such as genetic algorithms or neural networks. The current trend in the area of ramp metering, as well as of other highway management strategies, is thus in further combination with other approaches and shift towards heterogeneous multi-agent applications.

As presented, several authors address the field of highway management using distributed intelligence. However, most of the presented results are in the architectural level. The future challenge is in implementing the provided methods and testing them in the real-world conditions, preferably compared to the common highway management system. 
doc. Ing. ONDŘEJ PŘIBYL, Ph.D.

E-mail: pribylo@fd.cvut.cz

České vysoké učení technické v Praze, Fakulta dopravní Ústav aplikované matematiky

Na Florenci 25, Praha 1, 11000, Česká Republika

Ing. MILAN KOUKOL, Ph.D.

E-mail: koukol@fd.cvut.cz

České vysoké učení technické v Praze, Fakulta dopravní

Ústav aplikované informatiky v dopravě

Konviktská 20, Praha 1, 11000, Česká Republika

Ing. JANA KUKLOVÁ

E-mail: kuklojan@fd.cvut.cz

České vysoké učení technické v Praze, Fakulta dopravní

Ústav aplikované matematiky

Na Florenci 25, Praha 1, 11000, Česká Republika

\section{VYUŽITÍ METOD SOFT COMPUTINGU V MANAGEMENTU DÁLNIC: PRU゚ŘEZ LITERATUROU}

Systémy managementu dálnic jsou využivány ke zlepšení bezpečnosti a komfortu jízdy za pomoci řídicích strategii či napřiklad poskytování informací a varování pro řidiče. Mezi tyto strategie patři napríklad změny rychlostních limitů, alternativní využití jizdních pruhů, detekce dopravních nehod a informování o nich, varovných systémü, ramp meteringu, informování o počasí či o alternativní cestě. Tento článek uvádí přehled stávajících přístupů $k$ systémům řizení dálnic $v$ oblasti harmonizace rychlostí a ramp meteringu. Zaměřuje se na moderní a pokročilé přistupy, jako je soft computing, multi-agentní metody a jejich propojení. Cílem je poskytnou přehled a poukázat na aktuální výzkum, který ukazuje, že $v$ oblasti řizeni dálnic je stále vysoký potenciál pro dalši zlepšení.

\section{KLÍČOVÁ SLOVA}

řizení dopravy; management dálnic; kongesce; soft computing; multi-agentni systémy;

\section{REFERENCES}

[1] Přibyl O. An integrated model predictive highway management system. 1st ed. VDM Verlag; 2010.

[2] Srinivasan D, Sanyal S, Tan W.W. Hybrid Neuro-Fuzzy Technique for Automated Traffic Incident Detection. Proceedings of the International Joint Conference on Neural Networks (IJCNN); 2006 July 16-21; Vancouver, Canada; 2006. p. 713-719.

[3] Ma Y, Chowdhury M, Jeihani M, Fries R. Accelerated incident detection across transportation networks using vehicle kinetics and support vector machine in cooperation with infrastructure agents. IET Intelligent Transport Systems. 2010;4(4):328-337.

[4] Hegyi A, De Schutter B, Hellendoorn H. Model predictive control for optimal coordination of ramp metering and variable speed limits. Transportation Research C: Emerging Technologies. 2005;13(3):185-209.

[5] Wang W, Xu W, Yang Z, Zhao D. Research on a Support-Vector-Machine-Based Variable Speed Limits Control Model. Proc. Int. Conf. Transportation, Mechanical, and Electrical Engineering (TMEE). Changchun. China. December 2011:2234-2238.
[6] Pang MB, He GG. Chaos Rapid Recognition of Traffic Flow by Using Rough Set Neural Network. Proceedings of International Symposium on Information Processing (ISIP); Moscow, Russia; May 2008. p. 168172.

[7] Pribyl O. Computational intelligence in transportation: Short user-oriented guide. In: Goulias, KG, editor. Transport Science and Technology. Elsevier, 200; p. 37-54.

[8] Jang JSR, Sun C-T, Mizutani, E. Neuro-fuzzy and soft Computing. Prentice Hall; 1997.

[9] Loia V, editor. Soft Computing Agents. A New Perspective for Dynamic Information Systems. Vol. 83 of Frontiers in Artificial Intelligence and Applications. IOS Press; 2003.

[10] Bundesanstalt für Straßenwessen. MARZ: Merkblatt für die Ausstattung von Verkehrsrechnerzentralen und Unterzentralen. Dieses Merkblatt wurde aufgestellt von einem Bund/Länder-Arbeitskreis unter Leitung der BASt; 1999.

[11] Kühne RD, Langbein K. Optimierung der Parameter einer Linienbeein-flussungsanlage. In: Tagungsbericht Heureka 93. Karlsruhe 1993; p. 116-139.

[12] Gu S, Ma J, Wang J, Sui X, Liu Y. Methodology for Variable Speed Limit Activation in Active Traffic Management. Procedia - Social and Behavioral Sciences. 2013;96:2129 2137.

[13] Allaby P, Hellinga B, Bullock M. Variable Speed Limits: Safety and Operational Impacts of a Candidate Control Strategy for Freeway Applications. IEEE Transactions on Intelligent Transportation Systems. 2007;8(4):671680.

[14] Jo Y, Kim Y, Jung I. Variable Speed Limit to Improve Safety near Traffic Congestion on Urban Freeways. International Journal of Fuzzy Systems. 2012;14(2):278288.

[15] Vukanovic S, Kates R, Denaes S, Keller H. A novel algorithm for optimized, safety oriented dynamic speed regulation on highways: INCA. Proceedings of the 8th International IEEE Conference on Intelligent Transportation Systems; 2005 Sep 13-15; Vienna, Austria; 2005. p. 378383.

[16] Sasaki T, Akiyama T. Development of fuzzy traffic control system on urban expressway. Preprints 5th IFAC/ IFIP/IFORS Int. Conf. Transportation Systems. Vienna. Austria; July 1986. p. 333-338.

[17] Sasaki T. Akiyama T. Fuzzy on-ramp control model on urban expressway and its extension. In: Gartner NH, Wilson NHM, editors. Transportation and traffic theory. Elsevier, 1987; p. 377-395.

[18] Wang Y, Bin W, Hui Z. The National Freeway Control System - Further Development with Fuzzy Logic Theory. Proc. IEEE Int. Conf. Industrial Technology. Guangzhou. China; December 1994. p. 729-733.

[19] Bellman R. Adaptive Control Processes. A Guided Tour. Princeton University Press; 1961.

[20] Placer J, Sagahyroon A. Fuzzy Variable Speed Limit Device Project. Report No. FHWA-AZ98-466. Arizona Department of Transportation; 1998.

[21] Placer J. Fuzzy Variable Speed Limit Device Modification and Testing - Phase II. Report No. AZ-466(2). Arizona Department of Transportation; 2001.

[22] Roshandeh AM, Puan OC, Joshani M. Data Analysis Application for Variable Message Signs Using Fuzzy Logic 
in Kuala Lumpur. Int. Journal of Systems Applications. Engineering \& Development. 2009;3(1):18-27.

[23] Chiou YC, Lan LW. Genetic fuzzy logic controller: an iterative evolution algorithm with new encoding method. Fuzzy Sets and Systems. 2005;152(3):617-635.

[24] Chiou YC, Huang YF, Lin PC. Optimal variable speed-limit control under abnormal traffic conditions. Journal of The Chinese Institute of Engineers. 2012;35(3):299 308.

[25] Hadj-Salem H, Blosseville JM, Papageorgiou M. ALINEA. A local feedback control law for on-ramp metering; a real-life study. Proc. 3rd Int. Conf. Road Traffic Control. London, UK; May 1990. p. 194-198.

[26] Papageorgiou M, Hadj-Salem H, Blosseville JM. ALINEA: A local feedback control law for on-ramp metering. Transport Research Record. 1991;1320:58-64.

[27] Papamichail I, Papageorgiou M. Traffic-Responsive Linked Ramp-Metering Control. IEEE Transactions on Intelligent Transportation Systems. 2008;9(1):111 121.

[28] Hadi MA. Coordinated traffic responsive ramp metering strategies - An assessment based on previous studies. Proc. 12th World Congress on ITS. San Francisco, USA. November 2005.

[29] Jacobson L, Stribiak J, Nelson L, Sallman D. Ramp Metering and Control Handbook. Report No. FHWAHOP-06-001. U.S. Department of Transportation; 2006.

[30] Lu GX, Liu H. Ramp metering. Transportation Research Circular: Artificial Intelligence Applications to Critical Transportation Issues. 2012;E-C168:70-75.

[31] Murat, YS, Cakici Z, Yaslan G. Use of Fuzzy Logic Traffic Signal Control Approach as Dual Lane Ramp Metering Model for Freeways. Proc. 17th Online World Conf. Soft Computing in Industrial Applications. Ostrava, Czech Republic; December 2012. p. 339-349.

[32] Akçelik R. Issues in performance assessment of sign-controlled intersections. Proc. 25th ARRB Conf. Perth, Australia; September 2012.

[33] Hsu, TP, Hsieh TH. Development of Ramp Metering Using Fuzzy Logic Control Algorithm on Freeway. Proc. Eastern Asia Society for Transportation Studies. vol. 9; 2013.

[34] Jiang T, Liang X. Fuzzy Self-Adaptive PID Controller for Freeway Ramp Metering. Proc. Int. Conf. Measuring Technology and Mechatronics Automation (ICMTMA). Zhangjiajie, China; April 2009. p. 570-573.

[35] Zhang HM, Ritchie SG. Freeway ramp metering using artificial neural networks. Transportation Research Part C: Emerging Technologies. 1997;5(5):273-286.

[36] Feng Ch, Yuanhua J, Jian L, Huixin Y, Zhonghai N. Design of Fuzzy Neural Network Control Method for Ramp Metering. Proc. 3rd Int. Conf. Measuring Technology and Mechatronics Automation (ICMTMA). Shanghai, China; January 2011. p. 966-969.

[37] Ghods AH, Kian AR, and Tabibi M. A Genetic-Fuzzy Control Application to Ramp Metering and Variable Speed Limit Control. Proc. IEEE Int. Conf. Systems. Man and Cybernetics. Montreal, Canada; October 2007. p. 1723-1728.

[38] Ghods AH, Kian AR, Tabibi M. Adaptive Freeway Ramp Metering and Variable Speed Limit Control: A Genetic-Fuzzy Approach. IEEE Intelligent Transportation Sys- tems Magazine. 2009;1(1):27-36.

[39] Messmer A, Papageorgiou M. METANET: A macroscopic simulation program for motorway networks. Traffic Engineering \& Control. 1990;31(9):466-470.

[40] Yu XF, Xu WL, Alam F, Potgieter J, Fang CF. Genetic fuzzy logic approach to local ramp metering control using microscopic traffic simulation. Proc. 19th Int. Conf. Mechatronics and Machine Vision in Practice (M2VIP). Auckland, New Zealand; November 2012. p. 290-297.

[41] Lu XY, Varaiya P, Horowitz R, Su D, Shladover SE. A New Approach for Combined Freeway Variable Speed Limits and Coordinated Ramp Metering. Proc. 13th Int. IEEE Conf. Intelligent Transportation Systems (ITSC). Funchal, Portugal; September 2010. p. 491-498.

[42] Roseman D. Incident manager control concept multi-agency coordinated traffic management Santa Monica Freeway Smart Corridor. Proc. 64th ITE Annual Meeting Compendium of Technical Papers. Dallas, USA; 1994. p. 528-532.

[43] Logi F, Ritchie SG. A multi agent architecture for cooperative inter jurisdictional traffic congestion management. Transportation Research Part C: Emerging Technologies. 2002;10(5-6):507-527.

[44] Logi F. CARTESIUS: A Cooperative Approach to Real-Time Decision Support for Multi-Jurisdictional Traffic Congestion Management [PhD thesis]. University of California; 1999.

[45] van Katwijk RT, van Koningsbruggen P. Coordination of traffic management instruments using agent technology. Transportation Research Part C: Emerging Technologies. 2002;10(5-6):455-471.

[46] van Katwijk RT, van Koningsbruggen P, De Schutter B, Hellendoorn J. A Test Bed for Multiagent Control Systems in Road Traffic Management. In: Klügl F, Bazzan A, Ossowski S, editors. Applications of Agent Technology in Traffic and Transportation Research Record. Birkhäuser, 2005; p. 113-131.

[47] Hernández JZ, Ossowski S, García-Serrano A. Multiagent Architectures for Intelligent Traffic Management Systems. Transportation Research Part C: Emerging Technologies. 2002;10(5-6):473-506.

[48] Cuena J, Hernández JZ, Molina M. Knowledge-based models for adaptive traffic management systems. Transportation Research Part C: Emerging Technologies. 1995;3(5):311-337.

[49] Cuena, J, Hernández JZ, Molina M. Knowledge oriented design of an application for real time traffic management: The TRYS system. Proc. European Conf. Artificial Intelligence (ECAI). Budapest, Hungary; August 1996. p. 308-312.

[50] Ossovski S, Cuena J, García-Serrano A. A Case of Multiagent Decision Support: Using Autonomous Agents for Urban Traffic Control. Proc. 6th Ibero-American Conf. Al. Lisbon, Portugal; October 1998. p. 100-111.

[51] Ossovski S. Road Traffic Management. In: Co-ordination in Artificial Agent Societies. Berlin, Heidelberg: Springer-Verlag, 1999; p. 153-162.

[52] Tomás VR, Garcia LA. A Cooperative Multiagent System for Traffic Management and Control. Proc. 4th Int. Joint Conf. Autonomous Agents and Multiagent Systems (AAMAS). Utrecht, Netherlands; July 2005. p. 52-59. 
[53] van Katwijk RT, De Schutter B, Hellendoorn J. MultiAgent Coordination of Traffic Control Instruments. Proc. 1st Int. Conf. Infrastructure Systems and Services: Building Networks for a Brighter Future (INFRA). Rotterdam, Netherlands; November 2008. p. 1-6.

[54] Martí I, Tomás VR, Saez A, Martínez JJ. A Rule-based Multi-agent System for Road Traffic Management. Proc. IEEE/WIC/ACM Int. Joint Conf. Web Intelligence and Intelligent Agent Technologies. Milan, Italy; September 2009. p. 595-598.

[55] Almejalli K, Dahal K, Hossain A. An Intelligent Multiagent Approach for Road Traffic Management Systems. Proc. 18th IEEE Int. Conf. Control Applications (CCA). Saint Petersburg, Russia; July 2009. p. 825-830.
[56] Vilenica A, Renz W, Sudeikat J, Lamersdorf W. Multi-Agent-Architecture for Simulating Traffic Management - A Case Study on Highway Networks. Proc. 2nd Int. Workshop on Nonlinear Dynamics and Synchronization (INDS). Klagenfurt, Austria; July 2009. p. 121127.

[57] Tomás VR, Martí I, Sáez A, Martínez JJ. Agent-based test-bed for road information systems. IET Intelligent Transport Systems. 2012;6(4):404 412.

[58] Zhang X, Onieva E, Perallos A, Osaba E, Lee VCS. Hierarchical fuzzy rule-based system optimized with genetic algorithms for short term traffic congestion prediction. Transportation Research Part C: Emerging Technologies. June 2014;43(1):127-142. 